\title{
Column aerosol optical properties and aerosol radiative forcing during a serious haze-fog month over North China Plain in 2013 based on ground-based sunphotometer measurements
}

\author{
H. Che ${ }^{1}$, X. Xia ${ }^{2}$, J. Zhu' ${ }^{2}$, Z. Li ${ }^{3}$, O. Dubovik ${ }^{4}$, B. Holben ${ }^{5}$, P. Goloub ${ }^{4}$, H. Chen ${ }^{2}$, V. Estelles ${ }^{6}$, E. Cuevas-Agulló ${ }^{7}$,

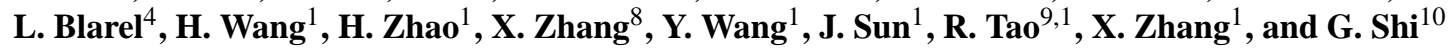 \\ ${ }^{1}$ Key Laboratory of Atmospheric Chemistry (LAC), Institute of Atmospheric Composition, Chinese Academy of \\ Meteorological Sciences (CAMS), CMA, Beijing, 100081, China \\ ${ }^{2}$ Laboratory for Middle Atmosphere and Global Environment Observation (LAGEO), Institute of Atmospheric Physics, \\ Chinese Academy of Sciences, Beijing, 100029, China Beijing, 100029, China \\ ${ }^{3}$ Institute of Remote Sensing and Digital Earth (RADI), Chinese Academy of Sciences, Beijing, 100094, China \\ ${ }^{4}$ Laboratoire d'Optique Amosphérique, Université des Sciences et Technologies de Lille, 59655 Villeneuve d'Ascq, France \\ ${ }^{5}$ Biospheric Sciences Branch, Code 923, NASA/Goddard Space Flight Center, Greenbelt, MD, USA \\ ${ }^{6}$ Dept. Fisica de la Terra i Termodinamica, Universitat de Valencia, C/ Dr. Moliner 50, 46100 Burjassot, Spain \\ ${ }^{7}$ Centro de Investigación Atmosférica de Izaña, AEMET, 38001 Santa Cruz de Tenerife, Spain \\ ${ }^{8}$ Institute of Urban Meteorology ,CMA, Beijing, 100089, China \\ ${ }^{9}$ College of Atmospheric Sciences, Chengdu University of Information Technology, Chengdu 610225, China \\ ${ }^{10}$ State Key Laboratory of Numerical Modeling for Atmospheric Sciences and Geophysical Fluid Dynamics (LASG), \\ Institute of Atmospheric Physics, Chinese Academy of Sciences, Beijing, 100029, China
}

Correspondence to: H. Che (chehz@cams.cma.gov.cn) and X. Xia (xxa@mail.iap.ac.cn)

Received: 13 September 2013 - Published in Atmos. Chem. Phys. Discuss.: 13 November 2013

Revised: 13 January 2014 - Accepted: 18 January 2014 - Published: 25 February 2014

\begin{abstract}
In January 2013, North China Plain experienced several serious haze events. Cimel sunphotometer measurements at seven sites over rural, suburban and urban regions of North China Plain from 1 to 30 January 2013 were used to further our understanding of spatial-temporal variation of aerosol optical parameters and aerosol radiative forcing (ARF). It was found that Aerosol Optical Depth at $500 \mathrm{~nm}$ $\left(\mathrm{AOD}_{500 \mathrm{~nm}}\right)$ during non-pollution periods at all stations was lower than 0.30 and increased significantly to greater than 1.00 as pollution events developed. The Angstrom exponent (Alpha) was larger than 0.80 for all stations most of the time. $\mathrm{AOD}_{500 \mathrm{~nm}}$ averages increased from north to south during both polluted and non-polluted periods on the three urban sites in Beijing. The fine mode AOD during pollution periods is about a factor of 2.5 times larger than that during the non-pollution period at urban sites but a factor of 5.0 at suburban and rural sites. The fine mode fraction of AOD $_{675 m} \mathrm{~nm}$ was higher than $80 \%$ for all sites during January 2013. The
\end{abstract}

absorption $\mathrm{AOD}_{675 \mathrm{~nm}}$ at rural sites was only about 0.01 during pollution periods, while $\sim 0.03-0.07$ and $0.01-0.03$ during pollution and non-pollution periods at other sites, respectively. Single scattering albedo varied between 0.87 and 0.95 during January 2013 over North China Plain. The size distribution showed an obvious tri-peak pattern during the most serious period. The fine mode effective radius in the pollution period was about $0.01-0.08 \mu \mathrm{m}$ larger than during nonpollution periods, while the coarse mode radius in pollution periods was about $0.06-0.38 \mu \mathrm{m}$ less than that during nonpollution periods. The total, fine and coarse mode particle volumes varied by about $0.06-0.34 \mu^{3}, 0.03-0.23 \mu \mathrm{m}^{3}$, and $0.03-0.10 \mu \mathrm{m}^{3}$, respectively, throughout January 2013. During the most intense period (1-16 January), ARF at the surface exceeded $-50 \mathrm{~W} \mathrm{~m}^{-2},-180 \mathrm{~W} \mathrm{~m}^{-2}$, and $-200 \mathrm{~W} \mathrm{~m}^{-2}$ at rural, suburban, and urban sites, respectively. The ARF readings at the top of the atmosphere were approximately $-30 \mathrm{~W} \mathrm{~m}^{-2}$ in rural and $-40-60 \mathrm{~W} \mathrm{~m}^{-2}$ in urban areas. 
Positive ARF at the top of the atmosphere at the Huimin suburban site was found to be different from others as a result of the high surface albedo due to snow cover.

\section{Introduction}

Aerosol particles can result in direct radiative forcing and they also have indirect effects on clouds (Hansen et al., 1997). Despite a broad body of research on aerosols, their concentrations and optical properties remain one of the largest sources of uncertainty in current assessments and predictions of global climate change (Hansen et al., 2000; Ramanathan et al., 2001). Aerosol particles not only affect the climate, they can also cause other environmental and public health problems (Watson, 2005).

China has experienced rapid economic growth over the past three decades, characterised by expanding industrialization, explosive growth in cars and frequent anthropogenic activities. These changes have resulted in high aerosol loading levels (Qiu and Yang, 2000; Luo et al., 2001; Zhang et al., 2013b; Li et al., 2013), decreases in visibility (Che et al., 2007), solar radiation (Che et al., 2005; Liang and Xia, 2006; Xia, 2010) and air quality (Xu et al., 2002), especially in areas of eastern China such as the Jing-Jin-Ji (Beijing, Tianjin and Hebei) region (Xu et al., 2005; Li et al., 2007a, b, 2011; Ding et al., 2008), the Yangtze River Delta and parts of southern China such as around the Pearl River Delta (Wang et al., 2003; Gao et al., 2011).

Employing ground-based measurement networks is very useful and accurate when investigating aerosol optical properties (Holben et al., 2001). There are several well-known ground-based aerosol-monitoring networks that use sunphotometers such as the Aerosol Robotic Network-AERONET (Holben et al., 1998), PHOtométrie pour le Traitement Opérationnel de Normalisation Satellitaire (PHOTONS) (Goloub et al., 2008), AEROCAN (Bokoye et al., 2001), China Aerosol Remote Sensing Network (CARSNET) (Che et al., 2009a), and SKYNET network (Takamura and Nakajima, 2004). These networks have been used to measure direct and diffuse solar radiation and derived aerosol optical properties for the purpose of aerosol radiative forcing studies (Dubovik et al., 2002; Kim et al., 2004). There has been a wealth of research on the optical properties of aerosols above the Jing-Jin-Ji region of China in recent years (Cheng et al., 2008; Che et al., 2008; Fan et al., 2009; Chen et al., 2013; Li et al., 2013; Xia et al., 2013), which has resulted in a comprehensive understanding of the aerosol optical properties of this region (Eck et al., 2005). These researches will help not only to uncover the regional climate effect of aerosol particles and the mechanism of pollution event formation, but also will allow managers to control air quality better in the future.

The most frequent and serious particle matter (PM) pollution of this century appeared in January 2013 in eastern China, especially in the densely populated
North China Plain, which caused considerable public concerns (http://edition.cnn.com/2013/01/19/world/asia/ china-florcruz-pollution). The greatest instantaneous concentration of $\mathrm{PM}_{2.5}$ reached $1000 \mu \mathrm{g} \mathrm{m}^{-3}$ in some heavily polluted areas of Beijing (Zhang et al., 2013a). The objective of this study is to investigate aerosol optical properties and their direct radiative forcing in rural, suburban and urban regions of North China Plain during this serious pollution episode. These high temporal resolution aerosol optical property data could be used in the validation of haze-fog modelling in future. The main findings include: (1) temporal variations in aerosol optical properties over North China Plain; (2) inter-comparison of aerosol optical properties between pollution and non-pollution periods in North China Plain; and (3) the direct radiative forcing characteristics caused by pollution aerosol particles in North China Plain.

\section{Site description, instrumentation and analytical method}

\subsection{Site description and instrumentation}

Seven sites in North China Plain providing sun and sky scanning radiometer (Cimel Electronique CE-318) observations were selected in this study (Fig. 1). The geographical information and site description are shown in Table 1. The Shangdianzi rural site is located $150 \mathrm{~km}$ to the northeast of Beijing, which is regarded as the regional atmospheric background station because it is far away from large anthropogenic emission sources. Therefore, the measurements from Shangdianzi represent the basic characteristics of aerosols in North China Plain, especially in the Beijing-Tianjin-Hebei (JingJin-Ji) Metropolitan region (Tang et al., 2007; Che et al., 2009b). Stations such as the Institute of Remote Sensing and Digital Earth (RADI), the Chinese Academy of Meteorological Sciences (CAMS), and the Beijing Meteorological Observatory (Nanjiao) are located in the Beijing urban area. Measurements at these three stations not only reflect the aerosol characteristics in urban North China Plain, but also represent the aerosol characteristics in the north, middle and southern parts of the greater Beijing urban area, respectively (Che et al., 2009a). Xianghe and Huimin are two suburban sites in North China Plain, the measurements taken there reflecting the aerosol characteristics of suburban North China Plain (Xia et al., 2005). Similar to RADI, CAMS, and Nanjiao stations, the Tianjin site is located in the centre of Tianjin city, so that these measurements also reflect the aerosol characteristics of urban North China Plain. Among these seven sites, RADI, CAMS, and Xianghe stations are the AErosol RObotic NETwork-AERONET stations (Holben et al., 1998; Li et al., 2007, 2013). Shangdianzi, CAMS, Nanjiao, Tianjin, and Huimin belong to the China Aerosol Research Network-CARSNET (Che et al., 2009a). The CAMS 


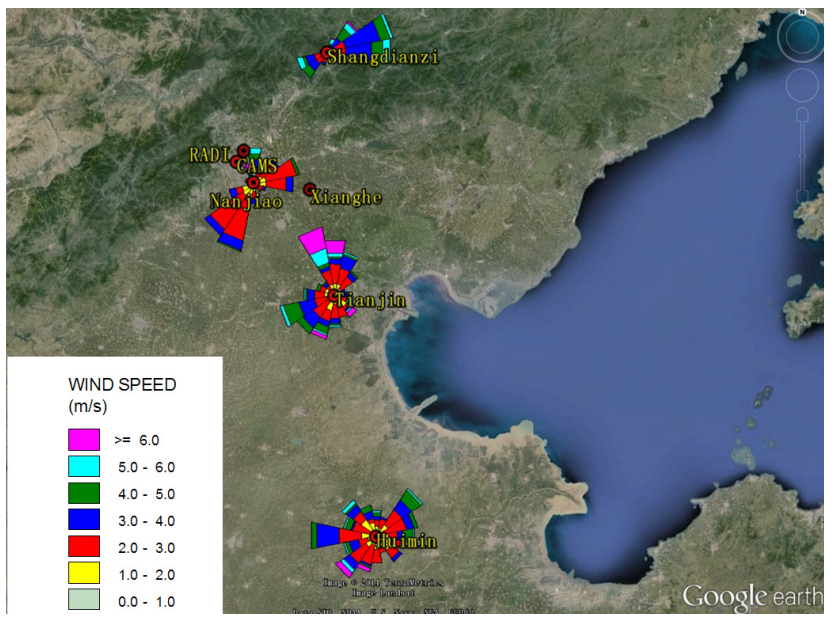

Fig. 1. Distribution of the seven sun photometer sites in North China Plain. Wind rose maps were plotted at Shangdianzi, Nanjiao, Tianjin, and Huimin, using observation data on the hourly meteorological wind speed and direction.

is the main station of CARSNET but the measurements are also uploaded to the AERONET data archive.

The Cimel Electronique CE-318 sunphotometer used in this research has eight channels, including 1640, 1020, 870, $670,500,440,380$ and $340 \mathrm{~nm}$ and a $940 \mathrm{~nm}$ water vapour channel with a $1.2^{\circ}$ full field-of-view (Holben et al., 1998). Measurements at 1640, 1020, 870, 670, 500, 440, 380 and $340 \mathrm{~nm}$ can be used to retrieve AOD, and measurements at $940 \mathrm{~nm}$ quantify in centimetres the total precipitable water vapour. The raw AOD is cloud-screened according to the method of Smirnov et al. (2000). The total uncertainty associated with the aerosol optical depth is approximately 0.010.02 (Eck et al., 1999). The sun photometer can also detect sky radiance for solar almucantar scenario or principal plane scenario measurements within a $1.2^{\circ}$ full field-of-view at $440,675,870$, and $1020 \mathrm{~nm}$. These sky radiance data are measured at 24 pre-defined scattering angles at regular time intervals, which are used to retrieve aerosol optical parameters such as single scattering albedo, size distribution, and refractive index, etc. (Dubovik and King, 2000; Dubovik et al., 2006).

In order to retain the accuracy of aerosol optical retrieval parameters, AERONET undertakes the Langley calibration at Mauna Loa (MLO, $19.54^{\circ} \mathrm{N}, 55.58^{\circ} \mathrm{W}, 3397.0 \mathrm{~m}$ ) and inter-comparison calibration and sphere calibration is conducted at the Goddard Space Flight Center (GSFC, $38.99^{\circ} \mathrm{N}, 76.84^{\circ} \mathrm{W}, 87.0 \mathrm{~m}$ ) periodically (Holben et al., 1998). AERONET-PHOTONS compiles the Langley calibration at the Izana Observatory in the Canary Islands (INM, Spain, $28.31^{\circ} \mathrm{N}, 16.50^{\circ} \mathrm{W}, 2391.0 \mathrm{~m}$ ) and Lille University (France, $50.61^{\circ} \mathrm{N}, 3.14^{\circ} \mathrm{E}, 60.0 \mathrm{~m}$ ) is responsible for intercomparison calibration and sphere calibration (Gloub et al., 2007). CARSNET records the Langley calibration at the
Izana Observatory (INM, Spain), following the calibration protocol used by NASA. The inter-comparison calibration is carried out at CAMS using an inter-comparison method (Che et al., 2009a). The sphere calibration is performed by the CARSENT sphere every year to ensure the accuracy of the sky irradiance measurement (Tao et al., 2014).

\subsection{Data description and analytical method}

In this study, the meteorological data from 1 to 30 January 2013 , including hourly relative humidity, wind speed and direction, has been obtained from the China Meteorological Administration (CMA). The hourly $\mathrm{PM}_{2.5}$ data for the same period in Beijing were supplied by the China National Environmental Monitoring Centre (http://www.cnemc.cn/). There are about 30 stations located in Beijing. The $\mathrm{PM}_{2.5}$ mass concentration data in this study was the average of all these stations, which could be representative of the entire Beijing. The wind frequency map was calculated using the $10 \mathrm{~min}$ wind data at Shangdianzi, Nanjiao, Tianjin and Huimin (Fig. 1). The daily averaged $\mathrm{PM}_{2.5}$, relative humidity and wind speed and wind direction at Beijing were calculated and are shown in Fig. 2. The Cimel sun photometer measurement was also selected for the same January period. Aerosol optical property and its radiative forcing data of RADI, CAMS, and Xianghe are from Level 1.5 data (cloud-screened) in the AERONET website (http://aeronet. gsfc.nasa.gov/). Aerosol optical property and its radiative forcing data for Shangdianzi, Nanjiao, Tianjin and Huimin collected from CARSNET were processed in a method similar to that used with AERONET (see next section).

\subsection{Retrieval methods of Cimel measurement of CARSNET}

The AOD data of the four CARSNET sites at Shangdianzi, Nanjiao, Tianjin and Huimin were processed using the ASTPwin software offered by Cimel Ltd. Co (Che et al., 2009a). This software is used to calculate Level 1.0 AOD (raw result without cloud-screening), Level 1.5 AOD (cloud-screened AOD based on the work of Smirnov et al., 2000) and the Angstrom Exponent (Alpha) between $440 \mathrm{~nm}$ and $870 \mathrm{~nm}$. Che et al. (2009a) pointed out that there is good consistency between the CARSNET calculation results and those of AERONET/PHOTONS. The daily averaged AOD is less than $2.05 \%, 0.46 \%, 1.50 \%$, and $2.61 \%$ at $1020 \mathrm{~nm}, 870 \mathrm{~nm}$, $670 \mathrm{~nm}$, and $440 \mathrm{~nm}$, respectively, based on comparison of the measurements between the three CARSNET instruments and AERONET/PHOTONS.

The retrieval processing method of sky radiance measurements used by CARSNET in this study is very similar to the Version 2 AERONET algorithm (Dubovik et al., 2006). In the AERONET Version 2 algorithm, the Cimel sky radiance measurements in the almucantar plane (fixed elevation angle equal to solar elevation and a full $360^{\circ}$ azimuthal sweep) at 
Table 1. Site location and description.

\begin{tabular}{lrrl}
\hline Station name & Lat $\left(^{\circ}\right)$ & Long $\left(^{\circ}\right)$ & Site description \\
\hline Shangdianzi & $40.65^{\circ} \mathrm{N}$ & $117.12^{\circ} \mathrm{E}$ & Rural station, 393.0 $\mathrm{m}$ a.s.l., $150 \mathrm{~km}$ to the northeast of Beijing city \\
RADI & $40.00^{\circ} \mathrm{N}$ & $116.38^{\circ} \mathrm{E}$ & Urban station, 59.0 m a.s.l., in the north part of Beijing \\
CAMS & $39.93^{\circ} \mathrm{N}$ & $116.32^{\circ} \mathrm{E}$ & Urban station, 105.0 m a.s.l., in the central part of Beijing \\
Nanjiao & $39.80^{\circ} \mathrm{N}$ & $116.47^{\circ} \mathrm{E}$ & Urban station, $31.3 \mathrm{~m}$ a.s.l., in the south part of Beijing \\
Xianghe & $39.75^{\circ} \mathrm{N}$ & $116.96^{\circ} \mathrm{E}$ & Suburban station, $36.0 \mathrm{~m}$ a.s.l., $50 \mathrm{~km}$ to the east of Beijing \\
Tianjin & $39.10^{\circ} \mathrm{N}$ & $117.17^{\circ} \mathrm{E}$ & Urban station, 3.3 m a.s.l., in the center of Tianjin City, 120 km to the southeast of Beijing \\
Huimin & $37.48^{\circ} \mathrm{N}$ & $117.53^{\circ} \mathrm{E}$ & Suburban station, $11.7 \mathrm{~m}$ a.s.l., 280 km to the southeast of Beijing \\
\hline
\end{tabular}

$440,675,870$, and $1020 \mathrm{~nm}$ (nominal wavelengths) in conjunction with the direct sun measured AOD at these same wavelengths $\left(\mathrm{AOD}_{440 \mathrm{~nm}}\right.$ should be larger than 0.40$)$ were used to retrieve column-integrated aerosol size distributions $(\mathrm{dV}(\mathrm{r}) / \mathrm{d} \ln (\mathrm{r})$ from 0.05 to $15 \mu \mathrm{m})$ and refractive indices, single scattering albedo, retrieved AOD, effective and median radii, volume concentration of fine and coarse mode aerosols at low solar elevations (solar zenith angles between 50 and 80 degrees) (Eck et al., 2010).

The radiative forcing and the forcing efficiency data at all sites in this study were calculated by the same radiative transfer module which has been integrated into the operational AERONET inversion code (García et al., 2012). This module uses the detailed size distribution, complex refractive index and fraction of spherical particles retrieved from Cimel sky radiance measurements in the almucantar plane (Dubovik and King, 2000; Dubovik et al., 2006) and provides the fluxes and aerosol radiative forcing (ARF) values using the Discrete Ordinates DISORT approach (Nakajima and Tanaka, 1988; Stamnes et al., 1988). Note that instantaneous ARF for solar zenith angle of $50-80^{\circ}$ is presented here.

\section{Results and discussion}

\subsection{Analysis of $\mathrm{PM}_{2.5}$ and meteorological data}

Before analysing the aerosol optical properties and its radiative forcing, we take measurements at Beijing as an example to investigate the temporal variation of $\mathrm{PM}_{2.5}$ and meteorological elements because these two factors contribute substantially to air pollution. Figure 2 shows the daily mean variation of $\mathrm{PM}_{2.5}$, relative humidity, and wind speed and direction in Beijing. According to the ambient air quality standards of China (GB 3095-2012: http://kjs.mep.gov.cn/hjbhbz/bzwb/dqhjbh/ dqhjzlbz/201203/t20120302_224165.htm), which will be implemented from 1 January 2016, air quality is regarded as a "pollution day" if the $24 \mathrm{~h}$ average of $\mathrm{PM}_{2.5}$ mass concentration exceeds $75 \mu \mathrm{g} \mathrm{m}^{-3}$. Thus, applying these criteria to the month of January 2013, there are 21 pollution days (polluted period) and only 10 non-pollution days (non-polluted period) over Beijing (Fig. 2a). The most intense pollution episode occurred from January 11 th to 17 th with the maximum $\mathrm{PM}_{2.5}$ mass concentration $>500 \mu \mathrm{g} \mathrm{m}^{-3}$ on 13 January. Temporal variation of relative humidity was consistent with that of $\mathrm{PM}_{2.5}$ (correlation coefficient being 0.58). On the pollution days, the relative humidity usually exceeded $50 \%$ (Fig. 2b). Hennigan et al. (2008) pointed out that the formation of secondary aerosol species such as $\mathrm{NO}_{3}^{-}, \mathrm{SO}_{4}^{2-}$ and secondary organic compounds could be enhanced under high-humidity conditions similar to the in-cloud process. In general, temporal variation of wind speed showed a negative relation with the $\mathrm{PM}_{2.5}$ (correlation coefficient being -0.25). During the polluted period, the wind speed was usually less than $2.0 \mathrm{~m} \mathrm{~s}^{-1}$ (Fig. 2c). However, a higher negative relation (correlation coefficient being -0.43) between wind speed and the $\mathrm{PM}_{2.5}$ on the next day also occurred in January 2013 in Beijing, indicating that wind speed is an important factor affecting $\mathrm{PM}_{2.5}$. Both low and high wind speed affected the accumulation and diffusion of aerosol particles during January 2013. The temporal wind direction variation is shown in Fig. 2d. Low $\mathrm{PM}_{2.5}$ concentrations usually coincide with northerly winds $\left(0-90^{\circ}, 270-360^{\circ}\right)$ on the previous day (e.g. $1-4,6,9$ and 20 January). The wind from the clean area to the north can reduce the pollutants and transport them to downstream region while, during the pollution period, wind direction on the previous day was close to southerly where anthropogenic activity is concentrated and frequent, especially in Hebei Province (Xia et al., 2007a). Apart from local emissions in Beijing, additional aerosol particles transported to Beijing can cause deterioration of the air quality. On the wind rose map (Fig. 1), the majority of wind frequencies during January 2013 at Beijing, Tianjin and Huimin come from the inland North China Plain where there are many industrial activities. Shangdianzi station is different from the others because the majority of wind frequencies are from the eastern mountain regions and the southwestern urban regions.

\subsection{Spatial variation of AOD, Angstrom exponent (Alpha), and volume size distribution (dV/dlnr) during January 2013 in North China Plain}

As the spatial and temporal variation of AOD at $500 \mathrm{~nm}$ can be seen on Fig. 3, AOD variation patterns were consistent 

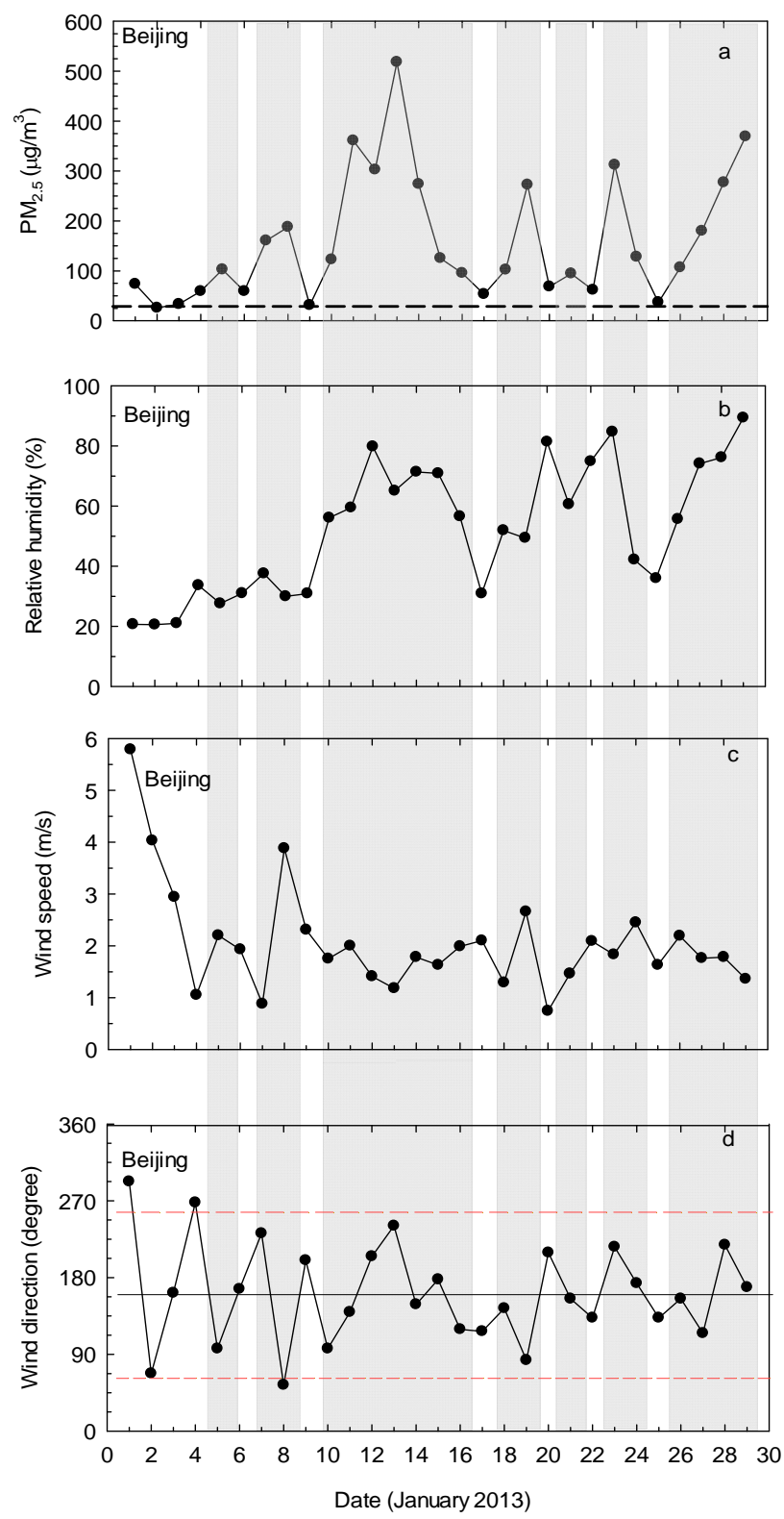

Fig. 2. Daily averaged $\mathrm{PM}_{2.5}$ (the dashed line indicates $75 \mu \mathrm{g} \mathrm{m}^{-3}$ ) (a), relative humidity (b), wind speed (c), wind direction (the upper red dash line indicates the wind from west and the bottom one indicates the wind from east) (d) at Beijing. The shaded area indicates daily $\mathrm{PM}_{2.5}$ exceeding $75 \mu \mathrm{g} \mathrm{m}^{-3}$.

in all rural, suburban, and urban regions during the pollution month of 2013. AOD values in the non-pollution period at all stations were lower than 0.30 and increased significantly to more than 1.00 as the pollution events occurred. This consistent variation indicates that intense pollution is not a local but a regional phenomenon in North China Plain. During the whole of January 2013, the daily AOD $_{500 \mathrm{~nm}}$ varied by about 0.15-2.60 (minimum 0.09, maximum 3.60) at CAMS, 0.132.79 (minimum 0.09, maximum 3.25) at Nanjiao, 0.12-2.70 (minimum 0.08, maximum 1.86) at RADI, 0.06-2.00 (minimum 0.05, maximum 2.51) at Shangdianzi, 0.08-2.12 (minimum 0.06, maximum 2.12) at Xianghe, 0.17-3.17 (minimum 0.06 , maximum 2.12) at Tianjin, and 0.17-2.39 (minimum 0.10 , maximum 2.87) at Huimin, respectively. AOD variation at the Shangdianzi station was consistent with those at RADI, CAMS, and Nanjiao, but the values were systematically lower than that in these three urban sites, suggesting that there are fewer anthropogenic pollution sources in this region. For the three urban sites of RADI, CAMS and Nanjiao located in Beijing, the AOD during the intense periods from 10 to 16 January and 26 to 29 January, AOD reached a level as high as $2.00-3.00$, which is similar to the previous results. $\mathrm{Li}$ et al. (2013) pointed out that the averaged AOD at $440 \mathrm{~nm}$ could reach 3.2 during thick haze events in Beijing. AOD variations at all four of the Beijing sites (Shangdianzi, RADI, CAMS, and Nanjiao) are consistent with those of $\mathrm{PM}_{2.5}$ (Fig. 2a). Li et al. (2013) pointed out that the correlation between $\mathrm{AOD}_{500 \mathrm{~nm}}$ and $\mathrm{PM}_{2.5}$ could reach 0.93 during haze events. In this study, the correlation between daily $\mathrm{AOD}_{500 \mathrm{~nm}}$ and $\mathrm{PM}_{2.5}$ during January 2013 was $0.82,0.75$ and 0.70 for RADI, CAMS, and Nanjiao, respectively, suggesting that the low level of atmosphere is well mixed during the pollution episode.

Figure 4 shows the spatial variation of Alpha during January 2013. It is obvious that the Alpha was larger than 0.80 for all stations and for most of the time, which suggests that the small aerosol particles was dominant during the pollution month over North China Plain. This result is similar to some previous ones (Eck et al., 2005; Xia, 2007a). During the two periods 12-16 and 24-29 January, the Alpha increased gradually at most stations, which suggests that the aerosol size became smaller as the pollution process developed. On 24 January, the Alpha values at Shangdianzi, RADI, CAMS, and Nanjiao were all lower than 0.80 , which suggests that coarse particles were dominant. This could be due to the decreasing relative humidity and increasing wind speed (Fig. 1). Coarse particles could be from more natural and anthropogenic dust emission with increasing wind speed. The $\mathrm{PM}_{2.5}$ decreased

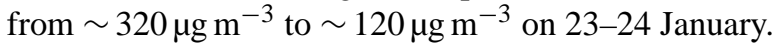

Figure 5 expresses the size distribution and spatial variation of particles at the three urban sites in Beijing. On polluted days, fine mode particles were clearly higher than in the non-polluted ones. In general, both fine and coarse mode particle volume increased gradually from 2 to 6 January at the three Beijing urban sites. In contrast to other polluted periods with only two peaks at the radius about $0.10-0.20 \mu \mathrm{m}$ and $1.20-1.40 \mu \mathrm{m}$, the size distribution showed an obvious tri-modal pattern during the most intense period (10-16 January) at the Beijing urban area. There were three peaks at the radius about $0.15 \mu \mathrm{m}, 0.30-0.50 \mu \mathrm{m}$, and $1.10-1.20 \mu \mathrm{m}$. This interesting phenomenon probably reflects the hygroscopic characteristics of fine particles. The relative humidity was more than $60 \%$ from 10 to 16 January. According to the results by Zhang et al. (2013a), the mean measured 


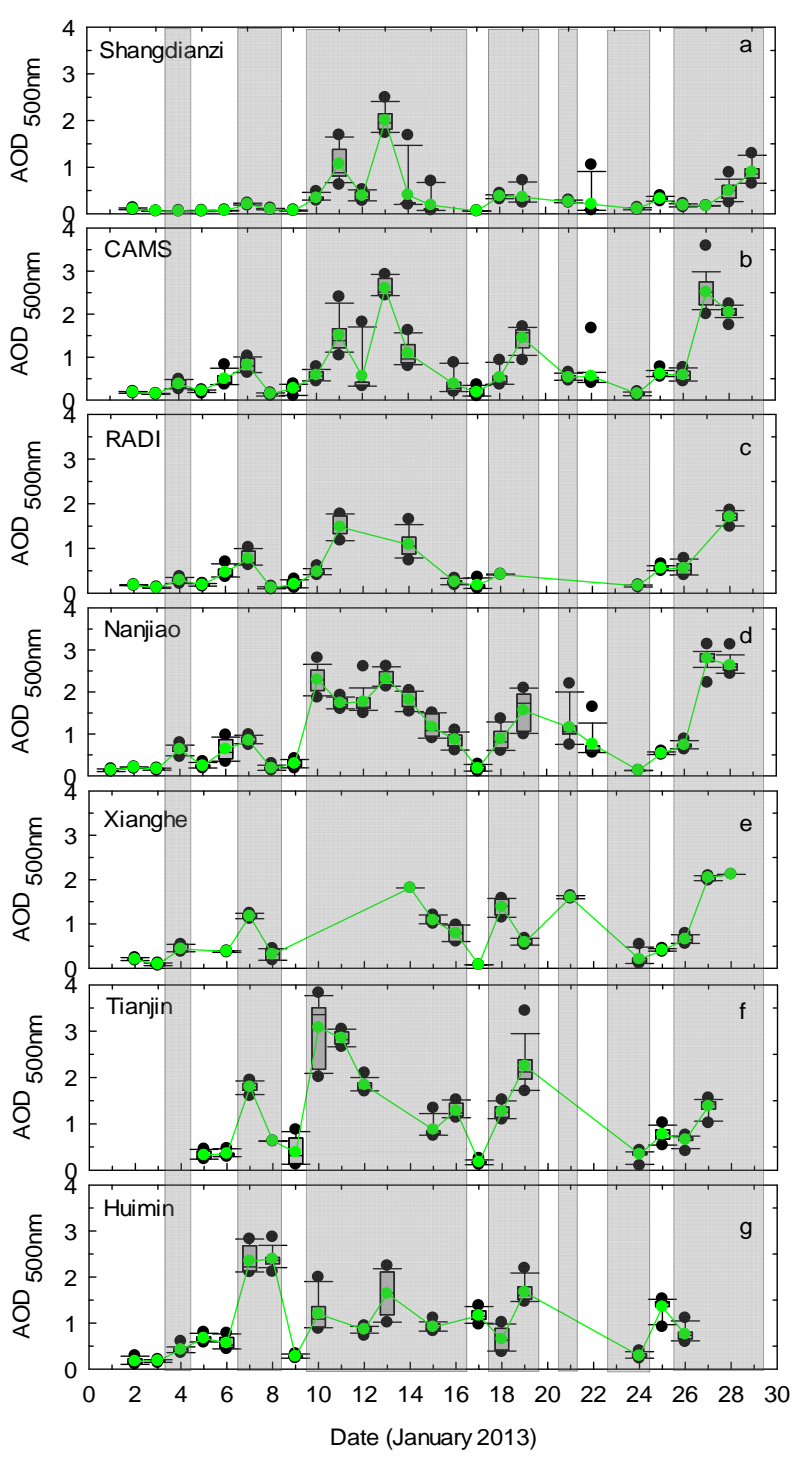

Fig. 3. Daily averaged AOD (green) and the 5th and 95th percentile box plots for the month of January 2013 at seven sites in North China Plain.

non-refractory submicron particle mass concentration at the Institute of Atmospheric Physics in Beijing (midway between the RADI and CAMS in this study) was composed of organics $(49.8 \%)$, sulphate $(21.4 \%)$, nitrate $(14.6 \%)$, ammonium $(10.4 \%)$, and chloride $(3.8 \%)$. These hygroscopic compositions could be one of the major reasons for the trimodal size distribution during the most intense haze period from 10 to 16 January. Another possible reason of the bimode submicron size distribution could be related to the haze-fog and cloud processing ( $\mathrm{Li}$ et al., 2011; Eck et al., 2012). The smaller mode ( 0.12 to 0.20 micron meter) may be interstitial aerosol that were not modified by incorporation in droplets and/or aerosol that are less hygroscopic in nature. The larger one is due to the haze-fog dissipation.

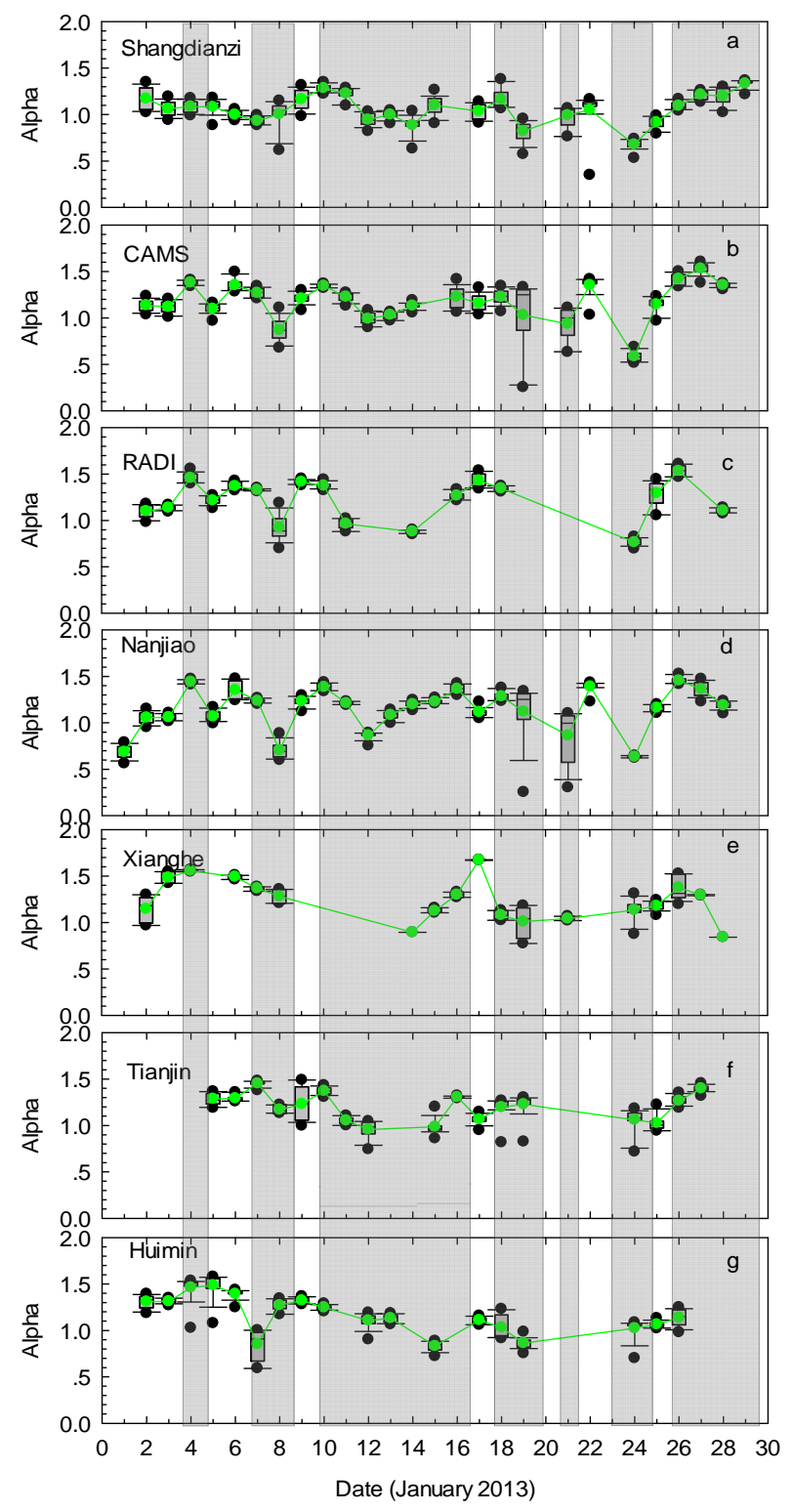

Fig. 4. Daily averaged Alpha (green) and its 5th and 95th percentile box plots for January 2013 at seven sites in North China Plain.

\subsection{Inter-comparison of aerosol optical properties during pollution and non-pollution periods}

According to the $\mathrm{PM}_{2.5}$ spatial variation in Beijing, the January 2013 period is divisible into the two periods, i.e. nonpollution and pollution period. In this section, aerosol optical characteristics between non-pollution and pollution periods are compared. Figure 6 shows the inter-comparison of $\mathrm{AOD}_{500 \mathrm{~nm}}$ (a), Alpha (b), fine mode $\mathrm{AOD}_{675 \mathrm{~nm}}$ (c), the fine mode $\mathrm{AOD}_{675 \mathrm{~nm}}$ fraction (d), absorption $\mathrm{AOD}_{675 \mathrm{~nm}}$ (e), and $\mathrm{SSA}_{675 \mathrm{~nm}}$ (f) during the two periods. $\mathrm{AOD}_{500 \mathrm{~nm}}$ during the pollution period is a factor of 2-4.3 times the nonpollution period. During the polluted period, the $\mathrm{AOD}_{500 \mathrm{~nm}}$ 


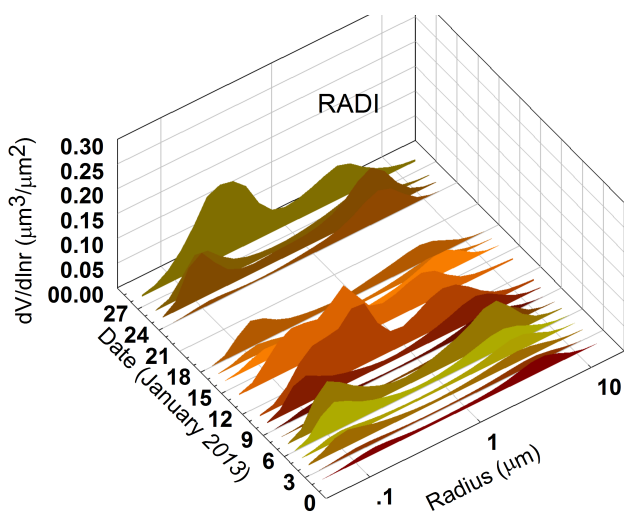

erages increased from the north (RADI) to the southern part (Nanjiao) during both the pollution and the non-pollution periods, which clearly reflected the effect of local emissions. The RADI site is located outside of Beijing's 4th ring road and near to the Olympic Forest Park where few industrial emissions occur. The CAMS is located between the 2 nd and 3rd Beijing ring road with heavier traffic loads compared to the RADI site, while the Nanjiao site is at a height of $31 \mathrm{~m}$ a.s.l. and only $200 \mathrm{~m}$ from the 5th Beijing ring road, where there are many factories near to the major ring road. Thus the higher local pollution may well contribute to the higher AOD found in the northern sites of CAMS and RADI.

The Alpha readings during both the pollution and non-

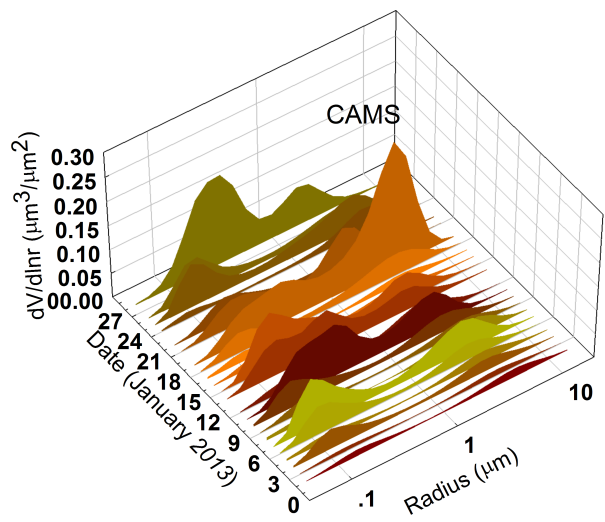
pollution periods are greater than 1.00 at all 7 sites, which suggest that the small particles are dominant. Alpha at Shangdianzi $(1.06 \pm 0.15)$ is lower than at the other sites, which indicates that the aerosol size in the rural site is larger than in the urban and suburban sites. This is because Shangdianzi is located about $100 \mathrm{~km}$ northeast of urban Beijing and surrounded by a mountain chain where is sparsely populated (Hänel et al., 2012). Thus fewer fine anthropogenic aerosol particles could affect this area. In contrast to the AOD, Alpha decreased from the north (RADI) to the southern location (Nanjiao) during both the polluted and non-polluted periods in Beijing, suggesting that larger size aerosol particles exist in the southern suburbs of Beijing.

The fine mode fraction of AOD was computed based on the retrieved size distributions and spectral refractive indices after the Dubovik and King (2000) algorithm applied to almucantar scans, assuming bimodal size distribution. This parameter is defined as the fraction of the total optical depth attributed to the fine mode of the aerosol size distribution, which could be used to discriminate aerosols with similar solar extinction but different sizes. The maximum radius of the fine mode volume distribution was defined as the minimum between the fine and coarse modes in the retrieved size distribution, over the defined range limits of $0.44-0.99 \mathrm{~m}$ radius. The minimum radius for the fine mode is fixed at a $0.05 \mathrm{~mm}$, which is the minimum radius of the almucantar inversion (Eck et al., 2010). During January 2013, large fine mode AODs were observed in Tianjin $(0.86 \pm 0.31)$ and Huimin $(0.48 \pm 0.36)$ (Fig. 6b). Xianghe was similar to Nanjiao with a fine mode AOD of $0.35 \pm 0.29$. The fine mode AOD at Shangdianzi during the same month was just 0.14 . The fine mode AOD in the pollution period at the urban sites of RADI, CAMS and Nanjiao was about a factor of 2.5 times the count in the non-pollution period, and a factor of about 5 on the suburban and rural sites. It can be seen in Fig. $6 \mathrm{~d}$ that the fine mode fraction of AOD $_{675 \mathrm{~nm}}$ (FMF) in January 2013 was larger than $80 \%$ for all sites, and was even greater (>90\%) at Tianjin and Huimin, indicating that the fine mode particles are the dominant contributor to the atmospheric extinction during January 2013 over North China Plain. This is similar to the results of Eck et al. (2010) and Xia et al. (2013), who

sites of RADI, CAMS and Nanjiao in Beijing, AOD $_{500 \mathrm{~nm}}$ av- 

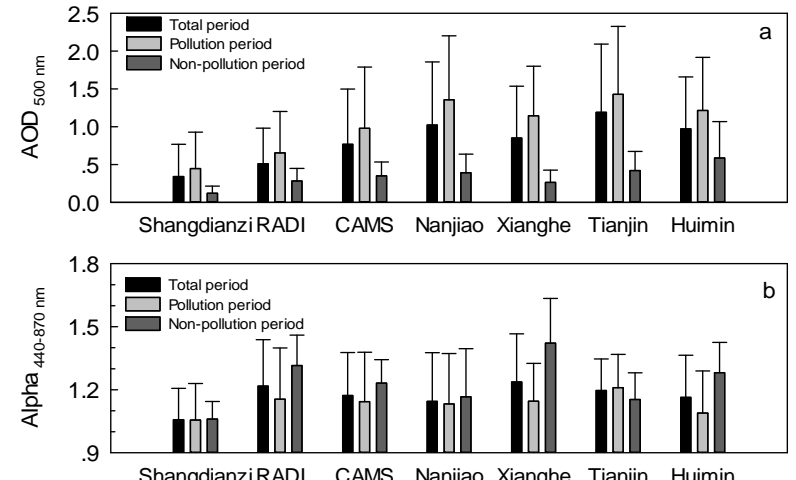

ShangdianziRADI CAMS Nanjiao Xianghe Tianjin Huimin
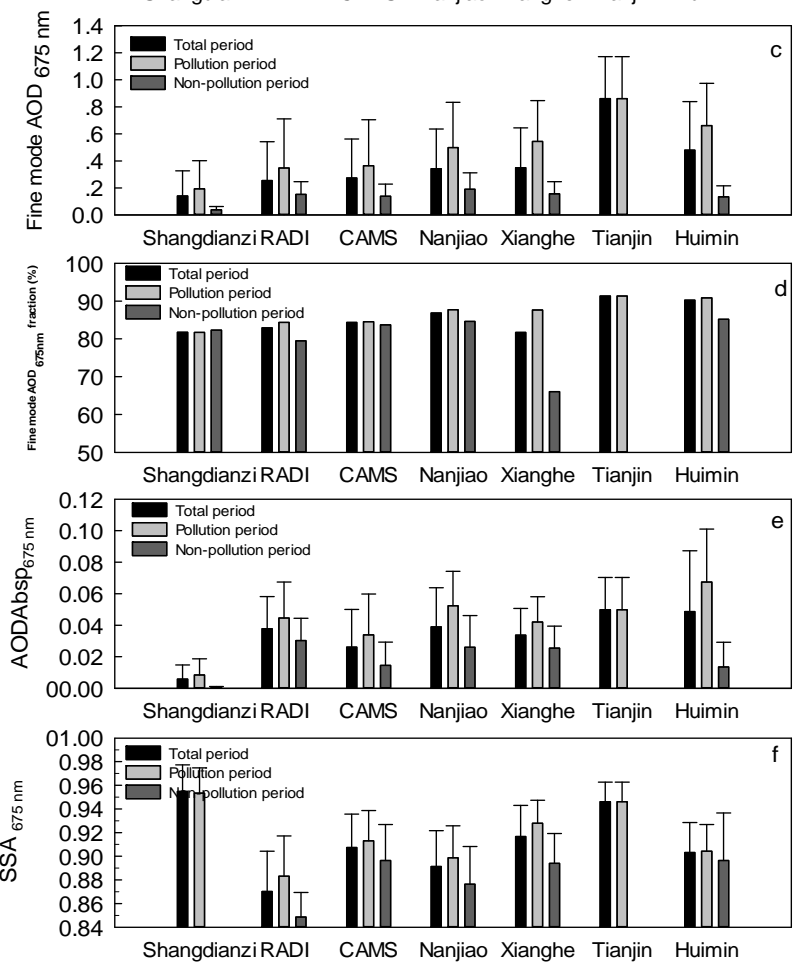

Fig. 6. Means of aerosol optical properties during the total period (January 2013), pollution period (daily $\mathrm{PM}_{2.5} \geq 75 \mu \mathrm{g} \mathrm{m}^{-3}$ ), and non-pollution period (daily $\mathrm{PM}_{2.5} \leq 75 \mu \mathrm{g} \mathrm{m}^{-3}$ ) at each site. (a) AOD at $500 \mathrm{~nm}$, (b) Alpha between $440-870 \mathrm{~nm}$, (c) Fine mode AOD at $675 \mathrm{~nm}$, (d) Fine mode AOD fraction at $675 \mathrm{~nm}$ (Fine mode $\mathrm{AOD}_{675 \mathrm{~nm}} /$ Total mode $\mathrm{AOD}_{675 \mathrm{~nm}}$ ), (e) Absorption AOD at $675 \mathrm{~nm}$, (f) Single scattering albedo at $675 \mathrm{~nm}\left(\mathrm{SSA}_{675 \mathrm{~nm}}\right)$.

pointed out that FMF could reach about 0.93 during most of the predominantly fine mode-dominated pollution cases.

Figure 6e shows the absorption $\mathrm{AOD}_{675 \mathrm{~nm}}(\mathrm{AAOD})$ at all sites during both the pollution and non-pollution periods. The AAOD at Shangdianzi was only about 0.01 during the pollution period while, for other sites, AAOD was about 0.030.07 and $0.01-0.03$ for pollution and non-pollution periods, respectively. This indicates that there were few absorption aerosol particles at the rural site of Shangdianzi and more absorption aerosol particles at both suburban and urban sites during the pollution period. These absorption aerosol particles may consist of black carbon and brown carbon emitted by coal combustion and vehicle exhausts (Zhang et al., 2012; Li et al., 2010). Li et al. (2013) found that the proportion of black carbon and brown carbon can reach between 25 and $38 \%$ during pollution events.

The single scattering albedo (SSA) varied between 0.87 and 0.95 in January 2013 at all seven sites (Fig. 6f). For the three Beijing urban sites and the two suburban sites of Xianghe and Huimin, the SSA values for the pollution period (0.88-0.93) are higher than for the non-pollution period (0.85-0.90), which could be due to the presence of watersoluble aerosols at higher relative humidity, resulting in fine mode particle growth and an increase in the light scattering coefficient (Kotchenruther and Hobbs, 1998).

Figure 7 shows the total, fine and coarse mode effective radii and volumes of aerosol particles during the pollution and non-pollution periods at all seven sites. The total mode effective radii varies from about 0.28 to $0.36 \mu \mathrm{m}$, 0.30 to $0.40 \mu \mathrm{m}$, and 0.23 to $0.41 \mu \mathrm{m}$ for the whole period, the pollution period and the non-pollution period, respectively (Fig. 7a). The fine mode effective radii varies in the ranges $0.14-0.23 \mu \mathrm{m}, 0.15-0.23 \mu \mathrm{m}$, and $0.13-0.15 \mu \mathrm{m}$ for the whole period, the pollution period and the non-pollution period, respectively (Fig. 7b), and the values of the coarse mode effective radii are about $2.21-2.46 \mu \mathrm{m}, 2.09-2.39 \mu \mathrm{m}$, and $2.10-2.62 \mu \mathrm{m}$ for the same series of periods (Fig. 7c). The fine mode effective radius of the pollution period is about $0.01-0.08 \mu \mathrm{m}$ larger than that found in the non-pollution period, which reflects the fine mode particle hygroscopic growth mentioned above. In contrast, the coarse mode radius in the pollution period was about $0.06-0.38 \mu \mathrm{m}$ less than that in the non-pollution period. It could be speculated that the higher wind speed during non-pollution periods results in more coarse particles in the atmosphere such as, for instance, the fugitive dust (Wang et al., 2009) and fly ash emissions from coal burning (Yang et al., 2009).

The total, fine and coarse mode particle volumes varied by $0.06-0.34 \mu \mathrm{m}^{3}, 0.03-0.23 \mu \mathrm{m}^{3}$, and $0.03-0.10 \mu \mathrm{m}^{3}$, respectively, during the whole month of January 2013 (Fig. 7de). During the pollution period, particle volumes were about $0.07-0.17 \mu \mathrm{m}^{3}, 0.03-0.12 \mu \mathrm{m}^{3}$, and $0.01-0.05 \mu \mathrm{m}^{3}$ larger than in the non-pollution period, which is suggestive of more aerosol loading (both fine and coarse mode particles) of the atmosphere during pollution periods over North China Plain.

\subsection{Analysis of aerosol radiative forcing (ARF) and its efficiency}

As pointed by García et al. (2012), the aerosol radiative forcing (ARF) provides the actual or total radiative effect of atmospheric aerosols. To make a consistent comparison among AFR of atmospheric aerosols the aerosol radiative forcing efficiency is a magnitude more appropriate. This parameter is 


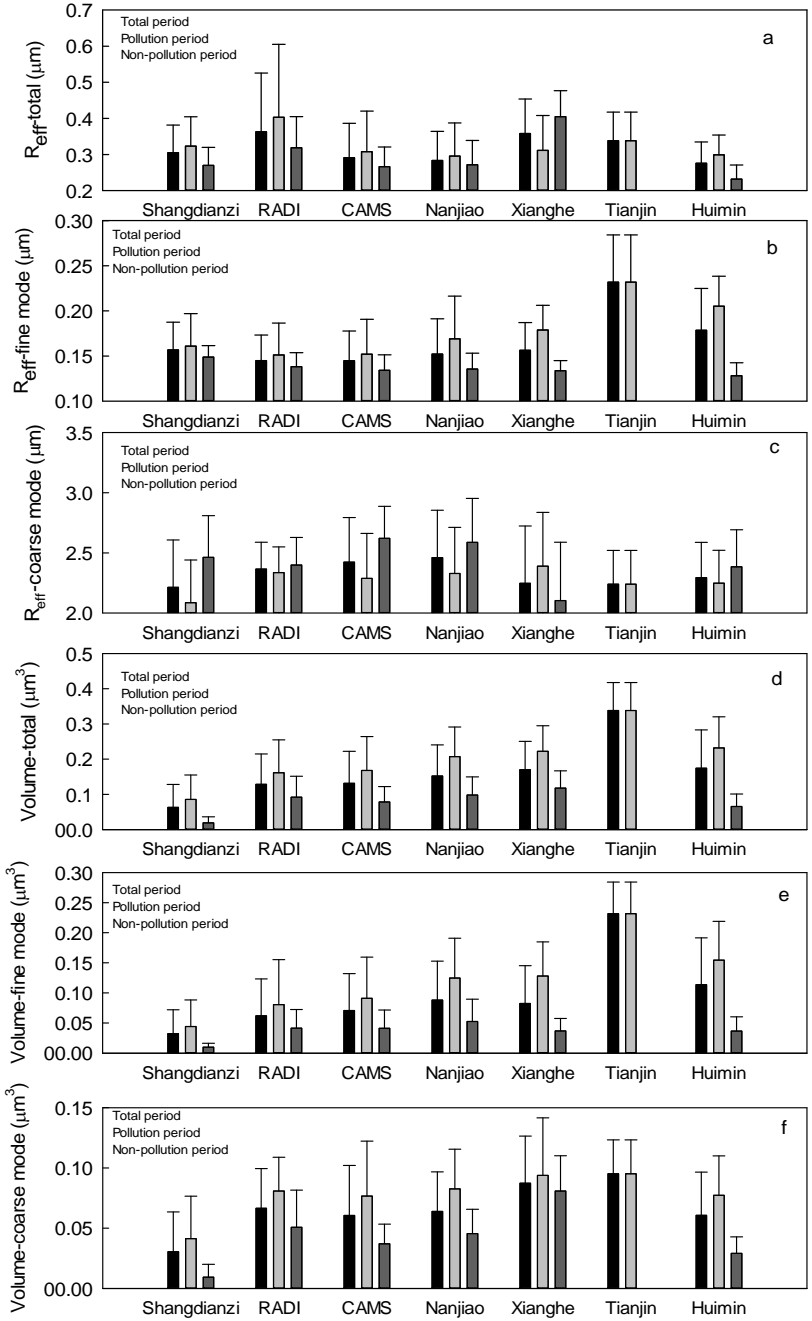

Fig. 7. Means of aerosol size distribution properties during the total period (January 2013), pollution period (daily $\mathrm{PM}_{2.5} \geq 75 \mu \mathrm{g} \mathrm{m}^{-3}$ ), and non-pollution period (daily $\mathrm{PM}_{2.5} \leq 75 \mu \mathrm{g} \mathrm{m}^{-3}$ ) at each site. (a) Retrieved effective radius of total mode; (b) retrieved effective radius of fine mode; (c) retrieved effective radius of coarse mode; (d) retrieved aerosol particle volume of total mode; (e) retrieved aerosol particle volume of fine mode; and (f) retrieved aerosol particle volume of coarse mode.

defined as the rate at which the atmosphere is forced per unit of AOD.

Figures 8 and 9 illustrate the spatial variations of ARF at the surface (ARF-BOA) and the top of the atmosphere (ARF-TOA) at the Shangdianzi, RADI, CAMS, Nanjiao and Huimin stations. As pollution levels became more intense during the periods 9-13 and 25-30 January, the ARFBOA values progressively increased (Fig. 8). During the most intense period (10-16 January), the ARF-BOA exceeded $-50 \mathrm{~W} \mathrm{~m}^{-2}$ at Shangdianzi; $-200 \mathrm{~W} \mathrm{~m}^{-2}$ at the three Beijing urban sites of RADI, CAMS, and Nanjiao; and $-180 \mathrm{~W} \mathrm{~m}^{-2}$ at the Huimin suburban site. The ARF-TOA varied with the same trends as the ARF-BOA at all sites during January 2013. During the most intense polluting period, the ARF-TOA values were $-30 \mathrm{~W} \mathrm{~m}^{-2}$ at Shangdianzi, and about $40-60 \mathrm{~W} \mathrm{~m}^{-2}$ at the three Beijing urban sites. However, the AFR-TOA spatial variation at Huimin was very different from the other sites. Before 4 January, the Huimin AFR-TOA was negative; this suggests that the aerosol particles imposed a cooling effect at the top of the atmosphere. From 5 January, the ARF-TOA at the same site became positive, which may have been a result of a heating effect by the aerosol particles at the top of the atmosphere. The reason for positive AFR-TOA is the presence of a large surface albedo (SA). (In this study, the surface albedo refers to records obtained from the MODerate-resolution Imaging Spectroradiometer (MODIS) albedo product (MCD43C3).) The precipitation records indicate that, from 20 December 2012, there were 3 days with a snow cover at Huimin. Thus, the MODIS albedo product showed surface albedo at $440 \mathrm{~nm}$ for Huimin, varying from 0.3498 to 0.5238 throughout the whole month of January 2013, which is much larger than the data from CAMS of 0.0645 to 0.094 on the same dates. García et al. (2012) points out that the effect of surface albedo on the AFR is critical for $\mathrm{SA}>0.30$. The high surface albedo could have caused more shortwave radiation reflecting back to the atmosphere and heating it by the absorption effect of aerosol particles (Wang et al., 2011). Finally, the high surface albedo was the cause of the positive ARF at the top of the atmosphere.

Figure 10 shows the ARF-BOA, the ARF-TOA and the efficiency of both during the whole period and the pollution and non-pollution periods. The ARF-BOA varied at all seven sites across North China Plain from -32 to $-144 \mathrm{~W} \mathrm{~m}^{-2}$, -43 to $-144 \mathrm{~W} \mathrm{~m}^{-2}$, and -9 to $-63 \mathrm{~W} \mathrm{~m}^{-2}$ for the whole, pollution and non-pollution periods, respectively, which indicates aerosol particles produce a cooling effect at this region. The ARF-TOA varied at all seven sites in North China Plain from 11 to $-54 \mathrm{~W} \mathrm{~m}^{-2}, 18$ to $-54 \mathrm{~W} \mathrm{~m}^{-2}$, and -3 to $-21 \mathrm{~W} \mathrm{~m}^{-2}$ for the whole, pollution and non-pollution periods, respectively. The ARF-TOA values are smaller than those in the ARF-BOA which suggests the aerosol particles higher absorption reduces the solar energy available to be backscattered to TOA and keep a larger percentage in the atmosphere. The ARF-BOA efficiencies are more than $-150 \mathrm{~W} \mathrm{~m}^{-2}$ for all sites except Tianjin $\left(-133 \pm 17 \mathrm{~W} \mathrm{~m}^{-2}\right)$ during the whole, pollution and non-pollution periods. The largest ARF-BOA efficiencies occurred in RADI sites with values of $-240 \pm 51 \mathrm{~W} \mathrm{~m}^{-2},-226 \pm 54 \mathrm{~W} \mathrm{~m}^{-2}$ and $-256 \pm 43 \mathrm{~W} \mathrm{~m}^{-2}$ during the whole, pollution and nonpollution periods, respectively. This could be due to the lower SSA values (less than 0.88) found at RADI. More absorbing aerosols can induce larger ARF efficiency at surface (García et al., 2012). The ARF-TOA efficiencies RADI, CAMS, Nanjiao and Xianghe show a set of similar levels as follows: -64 to $-87 \mathrm{~W} \mathrm{~m}^{-2},-55$ to $-77 \mathrm{~W} \mathrm{~m}^{-2}$ and -67 to $-100 \mathrm{~W} \mathrm{~m}^{-2}$ during the whole, pollution and 

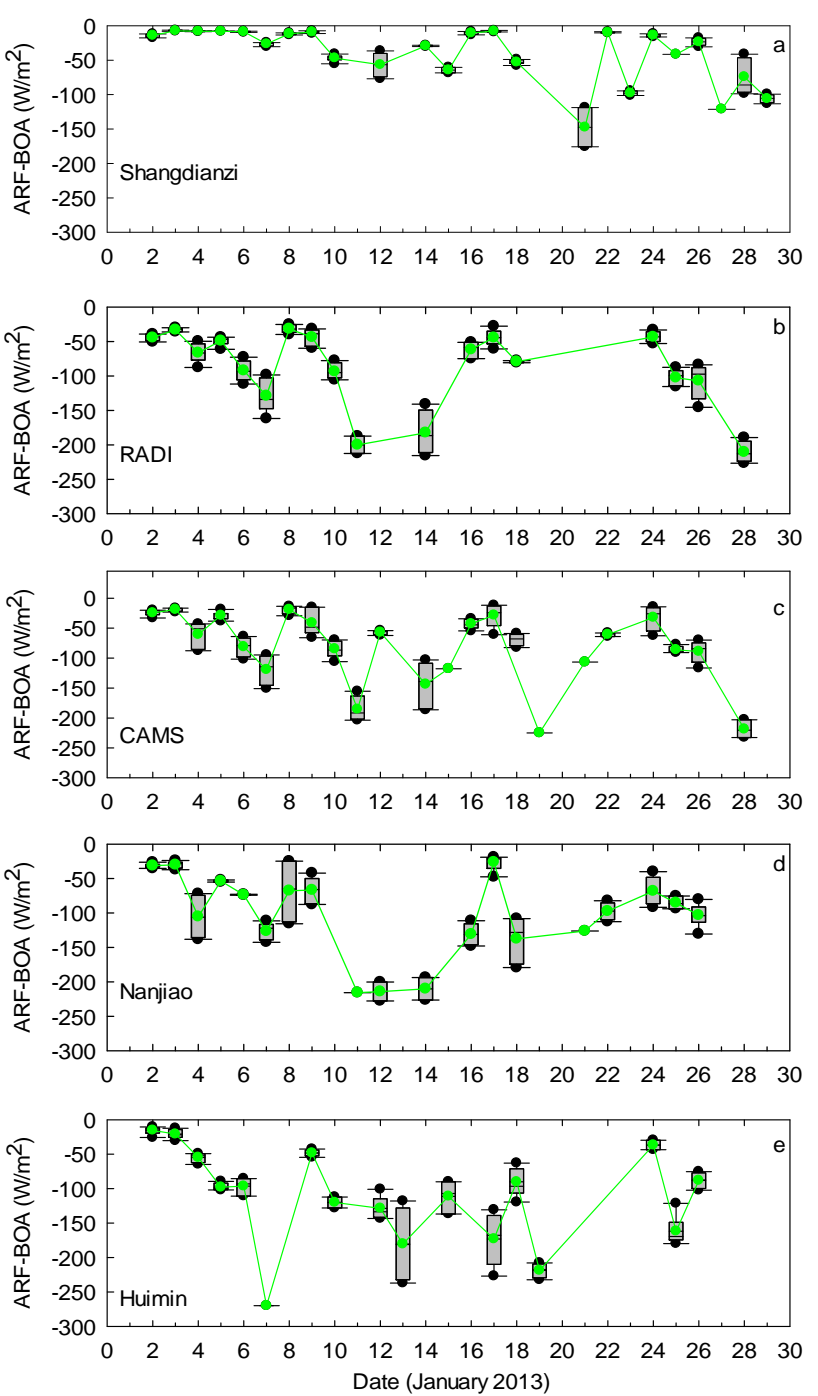

Fig. 8. Aerosol radiative forcing at the surface (ARF-BOA) and its 5th and 95th percentile box plots during January 2013 at five sites in North China Plain.

non-pollution periods, respectively. The Shangdianzi ARFTOA efficiencies are the highest among all 7 stations with values of $-121 \pm 21 \mathrm{~W} \mathrm{~m}^{-2},-114 \pm 23 \mathrm{~W} \mathrm{~m}^{-2}$, and $-134 \pm 10 \mathrm{~W} \mathrm{~m}^{-2}$ during the whole, pollution and nonpollution period, respectively. This is because the minimum AOD was observed there and ARF decreases with AOD (Xia et al., 2007b). García et al. (2012) pointed it clearly that even not significant uncertainties in the absolute values of radiative forcing at the low AOD can present more significant impact on relative to AOD values of forcing efficiency. The ARF-TOA efficiency at Huimin during the pollution periods was $18.89 \pm 18.85 \mathrm{~W} \mathrm{~m}^{-2}$, but $-32.36 \pm 40.78 \mathrm{~W} \mathrm{~m}^{-2}$ during the non-pollution periods. This positive ARF-TOA efficiency under the polluted condition is mainly due to the large surface reflectivity $(S A>0.30)$. While the negative ARF-
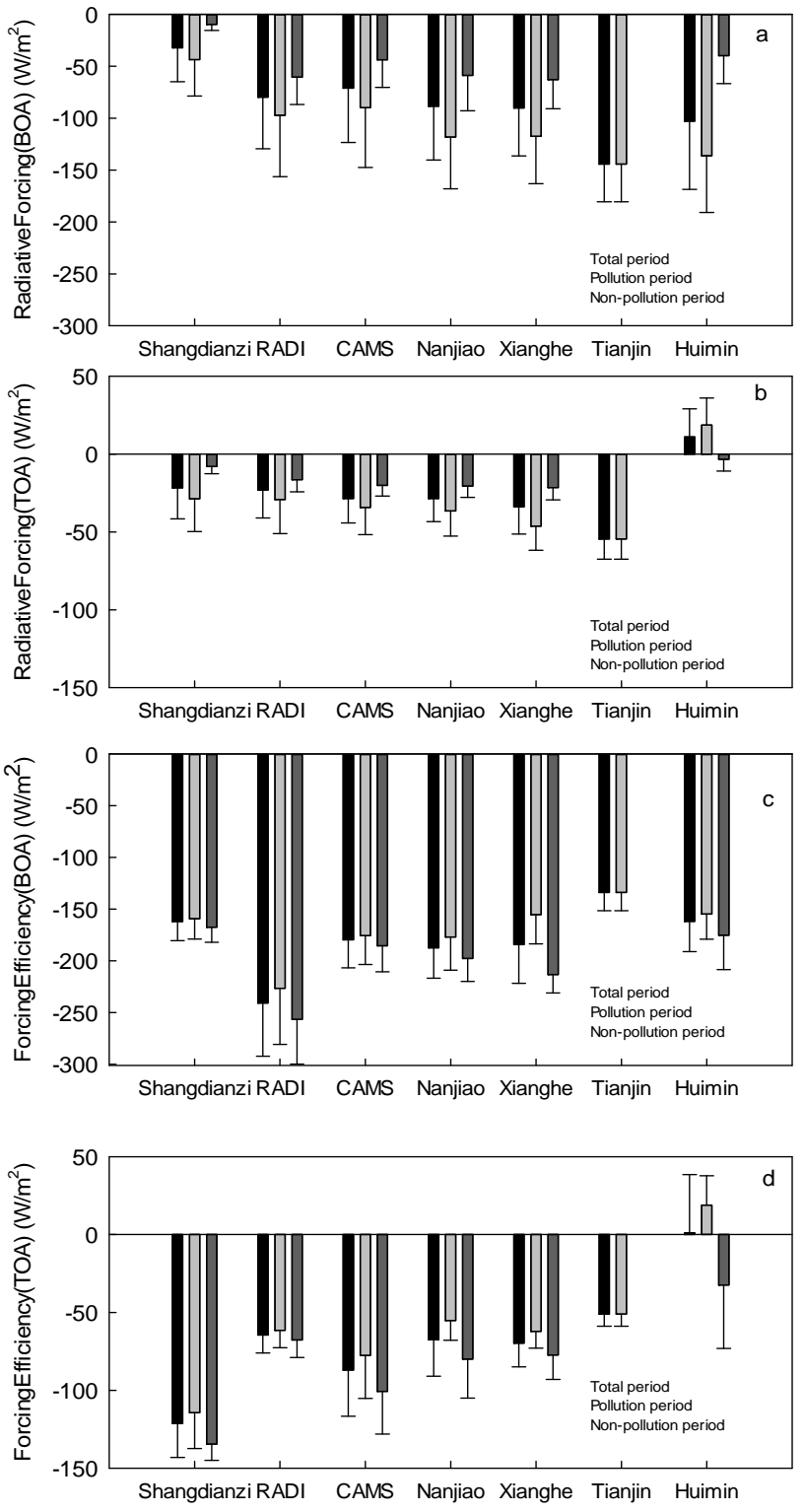

Fig. 9. Means of aerosol radiative forcing during the total period (January 2013), pollution period (daily $\mathrm{PM}_{2.5} \geq 75 \mu \mathrm{g} \mathrm{m}^{-3}$ ), and non-pollution period (daily $\mathrm{PM}_{2.5} \leq 75 \mu \mathrm{g} \mathrm{m}^{-3}$ ) at each site. (a) ARF-BOA, (b) ARF-TOA, (c) efficiency of ARF-BOA, (d) efficiency of ARF-TOA.

TOA efficiency under the non-polluted condition could probably be caused by faster increasing of backscattered energy towards the top of atmosphere in non-pollution conditions than under pollution ones. This faster increasing of backscattered energy towards TOA is not affected by aerosol scattering and absorption processes. 

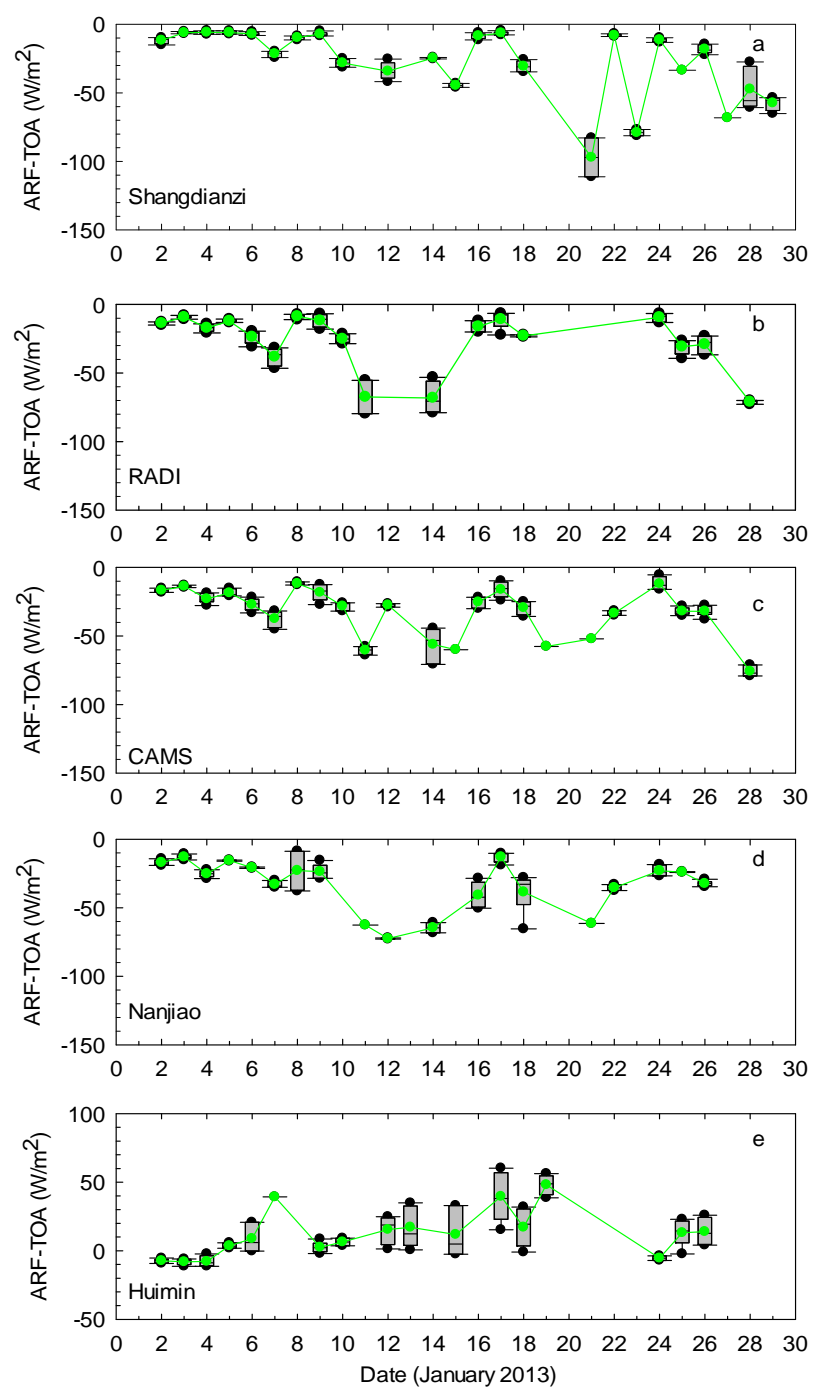

Fig. 10. Aerosol radiative forcing at the top of the atmosphere (ARF-TOA) and its 5th and 95th percentile box plots during January 2013 at five sites in North China Plain.

\section{Summary}

The aerosol optical properties and the radiative forcing over North China Plain during the intense pollution month in January 2013 can be summarised as follows.

Aside from the strong emissions based upon natural resources, meteorological conditions constitute a major contributor to the most intense pollution occurrence in January 2013. Relative humidity and wind are two important factors affecting the $\mathrm{PM}_{2.5}$ and aerosol optical properties.

The AOD at urban, suburban, and rural stations shows consistent variations during the pollution month in 2013, which indicates that serious pollution not a local but a regional phenomenon in North China Plain. AOD during the pollution period is 2 to 4.3 times higher than in the non-pollution pe- riod. Alpha was larger than 0.80 at all stations and for most of the time, which suggests that the small aerosol particle size was dominant during the 2013 pollution month. The fine mode AOD during the pollution period at urban sites is about a factor of 2.5 compared with the non-pollution period, and a factor of $\sim 5$ times the values in the suburban and rural sites. The fine mode fraction of $\mathrm{AOD}_{675 \mathrm{~nm}}$ (FMF) is larger than $80 \%$ at all sites, indicating that the fine mode particles were a main contributor to the atmospheric extinction during January 2013 over North China Plain. FMF during pollution periods is obviously larger than in non-pollution periods, which suggests that fine mode particles have a greater extinction effect during pollution periods. The absorption $\mathrm{AOD}_{675 \mathrm{~nm}}$ (AAOD) is only $\sim 0.01$ at rural sites but $\sim 0.03-0.07$ in suburban and urban sites during pollution periods, which registers the effect of more absorption aerosol particles at suburban and urban sites.

The single scattering albedo (SSA) varied between 0.87 and 0.95 during January 2013 at North China Plain. The fact that higher SSAs were observed during the pollution period than that during the non-pollution period points to the effect of fine mode particle growth and thereby the increase in the light scattering coefficient.

The size distribution shows an obvious tri-peak pattern during the most intense pollution period from 10 to $16 \mathrm{Jan}$ uary. The fine mode effective radius during pollution periods is about $0.01-0.08 \mu \mathrm{m}$ larger than that found in non-pollution periods, reflecting fine mode particle hygroscopic growth. Fine and coarse mode particle volumes during pollution periods are $\sim 0.03-0.12 \mu \mathrm{m}^{3}$ and $0.01-0.05 \mu \mathrm{m}^{3}$ larger than in non-pollution periods, indicative of more aerosol loading in the atmosphere during pollution periods.

The ARF-BOA varies from -32 to $-144 \mathrm{~W} \mathrm{~m}^{-2}$, from -43 to $-144 \mathrm{~W} \mathrm{~m}^{-2}$, and from -9 to $-63 \mathrm{~W} \mathrm{~m}^{-2}$ for the whole, pollution and non-pollution periods, respectively. The ARF-TOA is smaller than the ARF-BOA, the former varying from 11 to $-54 \mathrm{~W} \mathrm{~m}^{-2}, 18$ to $-54 \mathrm{~W} \mathrm{~m}^{-2}$ and -3 to $-21 \mathrm{~W} \mathrm{~m}^{-2}$ for the whole, pollution and non-pollution periods, respectively. During the January intense period, the ARF-BOA exceeded $-50 \mathrm{~W} \mathrm{~m}^{-2}$ at rural and -180 to $-200 \mathrm{~W} \mathrm{~m}^{-2}$ at suburban and urban sites. The ARF-TOA varied with the same trends as the ARF-BOA with the ARF $-30 \mathrm{~W} \mathrm{~m}^{-2}$ at rural and $-40-60 \mathrm{~W} \mathrm{~m}^{-2}$ at urban locations. Positive ARF-TOA at Huimin indicates that the aerosol particles generated a heating effect at the top of the atmosphere. This reflects the presence of a period with a large surface albedo resulting from a snow cover around the station during January 2013. The ARF-BOA efficiencies exceeded $-130 \mathrm{~W} \mathrm{~m}^{-2}$ during the whole, pollution and non-pollution period in North China Plain. The ARF-TOA efficiencies in rural sites are greater than at the suburban and urban sites with values of $-121 \pm 21 \mathrm{~W} \mathrm{~m}^{-2},-114 \pm 23 \mathrm{~W} \mathrm{~m}^{-2}$, and $-134 \pm 10 \mathrm{Wm}^{-2}$ during the whole pollution and non-pollution period, respectively, compared to -64 to $-87 \mathrm{~W} \mathrm{~m}^{-2},-55$ to $-77 \mathrm{~W} \mathrm{~m}^{-2}$, and -67 to $-100 \mathrm{~W} \mathrm{~m}^{-2}$ 
at suburban and urban locations. The ARF-TOA efficiency at Huimin during the pollution period is about $18.89 \pm$ $18.85 \mathrm{~W} \mathrm{~m}^{-2}$ compared to $-32.36 \pm 40.78 \mathrm{~W} \mathrm{~m}^{-2}$ during non-pollution periods.

In this article, the aerosol optical property data could be processed near real time (NRT), which is available as one of the most important input factors of haze data assimilation. These NRT aerosol optical property data could also be used in the validation of AOD and aerosol radiative forcing simulated by haze-fog modelling because their high temporal resolution and continuous measurement. The above applications both benefits to the improvement of haze-fog forecasting system and therefore accurate evaluation of radiative forcing and radiative feedbacks on haze weather system due to haze particles.

Acknowledgements. This work is financially supported by grants from the National Key Project of Basic Research (2011CB403401 and 2014CB441201), the Project (41005086, 41275167 and 41130104) supported by NSFC, the Strategic Priority Research Programme of the Chinese Academy of Sciences (Grant no. XDA05100301), CAMS Basis Research Project (2012Y02 and 2013Z007). Cimel master calibration of CARSNET was performed at the AERONET-EUROPE calibration center (LOA and AEMET-Tenerife), supported by ACTRIS (European Union Seventh Framework Programme (FP7/2007-2013) under grant agreement no. 262254.

Edited by: S. Gong

\section{References}

Bokoye, A. I., Royer, A., O’Neill, N. T., Cliche, P., Fedosejevs, G., Teillet, P. M., and McArthur, L. J. B.: Characterization of atmospheric aerosols across Canada from a Ground-based sunphotometer network: Aerocan, Atmos. Ocean., 39, 429-456, 2001.

Che, H., Zhang, X., Li, Y., Zhou, Z., and Qu, J. J.: Horizontal visibility trends in China 1981-2005, Geophys. Res. Lett., 34, L24706, doi:10.1029/2007GL031450, 2007.

Che, H., Shi, G., Uchiyama, A., Yamazaki, A., Chen, H., Goloub, P., and Zhang, X.: Intercomparison between aerosol optical properties by a PREDE skyradiometer and CIMEL sunphotometer over Beijing, China, Atmos. Chem. Phys., 8, 3199-3214, doi:10.5194/acp-8-3199-2008, 2008.

Che, H., Zhang, X. Y., Chen, H. B., Damiri, B., Goloub, P., Li, Z. Q., Zhang, X. C., Wei, Y., Zhou, H. G., Dong, F., Li, D. P., and Zhou, T. M.: Instrument calibration and aerosol optical depth validation of the China Aerosol Remote Sensing Network, J. Geophys. Res., 114, D03206, doi:10.1029/2008JD011030, 2009a.

Che, H., Yang, Z., Zhang, X., Zhu, C., Ma, Q., Zhou, H., and Wang, P.: Study on the aerosol optical properties and their relationship with aerosol chemical compositions over three regional background stations in China, Atmos. Environ., 43, 1093-1099, doi:10.1016/j.atmosenv.2008.11.010, 2009b.

Che, H. Z., Shi, G. Y., Zhang, X. Y., Arimoto, R., Zhao, J. Q., Xu, L., Wang, B., and Chen, Z. H.: Analysis of 40 years of solar radiation data from China, 1961-2000, Geophys. Res. Lett., 32, L06803, doi:10.1029/2004GL022322,2005.

Chen, H., Gu, X., Cheng, T., Li, Z., and Yu, T.: The spatial-temporal variations in optical properties of atmosphere aerosols derived from AERONET dataset over China, Meteorol. Atmos. Phys., 122, 65-73, doi:10.1007/s00703-013-0268-2, 2013.

Cheng, T. T., Zhang, R. J., Han, Z. W., and Fang, W.: Relationship between ground-based particle component and column aerosol optical property in dusty days over Beijing, Geophys. Res. Lett., 35, L20808, doi:10.1029/2008GL035284, 2008.

Ding, A. J., Wang, T., Thouret, V., Cammas, J.-P., and Nédélec, P.: Tropospheric ozone climatology over Beijing: analysis of aircraft data from the MOZAIC program, Atmos. Chem. Phys., 8, 1-13, doi:10.5194/acp-8-1-2008, 2008.

Dubovik, O. and King, M. D.: A flexible inversion algorithm for the retrieval of aerosol optical properties from Sun and sky radiance measurements, J. Geophys. Res., 105, 20673-20696, doi:10.1029/2000JD900282, 2000.

Dubovik, O., Holben, B. N., Eck, T. F., Smirnov, A., Kaufman, Y. J., King, M. D., Tanre, D., and Slutsker, I.: Variability of absorption and optical properties of key aerosol types observed in worldwide locations, J. Atm. Sci., 59, 590-608, 2002.

Dubovik, O., Sinyuk, A., Lapyonok, T., Holben, B. N., Mishchenko, M., Yang, P., Eck, T. F., Volten, H., Munoz, O., Veihelmann, B., van der Zande, W. J., Leon, J. F., Sorokin, M., and Slutsker, I.: Application of spheroid models to account for aerosol particle nonsphericity in remote sensing of desert dust, J. Geophys. ResAtmos., 111, D11208, doi:10.1029/2005jd006619, 2006.

Eck, T. F., Holben, B. N., Reid, J. S., Dubovik, O., Smirnov, A., O'Neill, N. T., Slutsker, I., and Kinne, S.: Wavelength dependence of the optical depth of biomass burning, urban, and desert dust aerosols, J. Geophys. Res., 104, 31333-31349, 1999.

Eck, T. F., Holben, B. N., Dubovik, O., Smirnov, A., Goloub, P., Chen, H. B., Chatenet, B., Gomes, L., Zhang, X. Y., Tsay, S. C., Ji, Q., Giles, D., and Slutske, I.: Columnar aerosol optical properties at AERONET sites in central eastern Asia and aerosol transport to the tropical mid-Pacific, J. Geophys. Res., 110, D06202, doi:10.1029/2004JD005274, 2005.

Eck, T. F., Holben, B. N., Sinyuk, A., Pinker, R. T., Goloub, P., Chen, H., Chatenet, B., Li, Z., Singh, R. P., Tripathi, S. N., Reid, J. S., Giles, D. M., Dubovik, O., O’Neill, N. T., Smirnov, A., Wang, P., and Xia, X.: Climatological aspects of the optical properties of fine/coarse mode aerosol mixtures, J. Geophys. Res., 115, D19205, doi:10.1029/2010JD014002, 2010.

Eck, T. F., Holben, B. N., Reid, J. S., Giles, D. M., Rivas, M. A., Singh, R. P., Tripathi, S. N., Bruegge, C. J., Platnick, S., Arnold, G. T., Krotkov, N. A., Carn, S. A., Sinyuk, A., Dubovik, O., Arola, A., Schafer, J. S., Artaxo, P., Smirnov, A., Chen, H., and Goloub, P.: Fog- and cloud-induced aerosol modification observed by the Aerosol Robotic Network (AERONET), J. Geophys. Res., 117, D07206, doi:10.1029/2011JD016839, 2012.

Fan, X. H., Chen, H. B., Lin, L. F., Han, Z. G., and Goloub, P.: Retrieval of Aerosol Optical Properties over the Beijing Area Using POLDER/PARASOL Satellite Polarization Measurements, Adv. Atmos. Sci., 26, 1099-1107, 2009.

Gao, L., Jia, G., Zhang, R., Che, H., Fu, C., Wang, T., Zhang, M., and Jiang, H.: Visual range trends in the Yangtze River Delta Region of China, 1981-2005, J. Air Waste Manage. Assoc., 61, 843-849, doi:10.3155/1047-3289.61.8.843, 2011. 
García, O. E., Díaz, J. P., Expósito, F. J., Díaz, A. M., Dubovik, O., and Derimian, Y.: Aerosol Radiative Forcing: AERONETBased Estimates, Climate Models, edited by: Druyan, L., ISBN: 978-953-51-0135-2, InTech, doi:10.5772/32287, available at: http://www.intechopen.com/books/climate-models/ aerosol-radiative-forcing-aeronetbased-estimates (last access: March 2013), 2012.

Goloub, P., Li, Z., Dubovik, O., Blarel, L., Podvin, T., Jankowiak, I., Lecoq, R., Deroo, C., Chatenet, B., Morel, J. P., Cuevas, E., and Ramos, R.: PHOTONS/AERONET sunphotometer network overview: description, activities, results, Proc. SPIE 6936, 69360V, doi:10.1117/12.783171, 2007.

Hänel, A., Baars, H., Althausen, D., Ansmann, A., Engelmann, R., and Sun, J. Y.: One-year aerosol profiling with EUCAARI Raman lidar at Shangdianzi GAW station: Beijing plume and seasonal variations, J. Geophys. Res., 117, D13201, doi:10.1029/2012JD017577, 2012.

Hansen, J., Sato, M., and Ruedy, R.: Radiative forcing and climate response, J. Geophys. Res., 102, 6831-6864, doi:10.1029/96JD03436, 1997.

Hansen, J., Sato, M., Ruedy, R., Lacis, A., and Oinas, V.: Global warming in the twenty-first century: An alternative scenario, Proc. Natl. Acad. Sci. USA, 97, 9875-9880, 2000.

Hennigan, C. J., Bergin, M. H., Dibb, J. E., and Weber, R. J.: Enhanced Secondary Organic Aerosol Formation due to Water Uptake by Fine Particles, Geophys. Res. Lett., 35, L18801, doi:10.1029/2008GL035046, 2008.

Holben, B., Tanre, D., Smirnov, A., Eck, T., Slutsker, I., Abuhassan, N., Newcomb, W. W., Schafer, J., Chatenet, B., Lavenue, F., Kaufman, Y., Castle, J. V., Setzer, A., Markham, B., Clark, D., Frouin, R., Halthore, R., Karnieli, A., O'Neill, N., Pietras, C., Pinker, R., Voss, K., and Zibordi, G.: An emerging ground-based aerosol climatology: Aerosol Optical Depth from AERONET, J. Geophys. Res., 106, 12067-12097, 2001.

Holben, B. N., Eck, T. F., Slutsker, I., Tanre, D., Buis, J. P., Setzer, A., Vermote, E., Reagan, J. A., Kaufman, Y., Nakajima, T., Lavenu, F., Jankowiak, I., and Smirnov, A.: AERONET-A federated instrument network and data archive for aerosol characterization, Remote Sens. Environ., 66, 1-16, 1998.

Kim, D. H., Sohn, B. J., Nakajima, T., Takamura, T., Takemura, T., Choi, B. C., and Yoon, S. C.: Aerosol optical properties over east Asia determined from ground-based sky radiation measurements, J. Geophys. Res., 109, D02209, doi:10.1029/2003JD003387, 2004.

Kotchenruther, R. A. and Hobbs, P. V.: Humidification factors of aerosols from biomass burning in Brazil, J. Geophys. Res., 103, 32081-32089, 1998.

Li, W., Li, P., Sun, G., Zhou, S., Yuan, Q., and Wang, W.: Cloud residues and interstitial aerosols from non-precipitating clouds over an industrial and urban area in northern China, Atmos. Environ., 45, 2488-2495, doi:10.1016/j.atmosenv.2011.02.044, 2011.

Li, W. J., Shao, L. Y., and Buseck, P. R.: Haze types in Beijing and the influence of agricultural biomass burning, Atmos. Chem. Phys., 10, 8119-8130, doi:10.5194/acp-10-8119-2010, 2010.

Li, Z., Li, C., Chen, H., Tsay, S.-C., Holben, B., Huang, J., Li, B., Maring, H., Qian, Y., Shi, G., Xia, X., Yin, Y., Zheng, Y., and Zhuang, G.: East Asian Studies of Tropospheric Aerosols and their Impact on Regional Climate (EAST ${ }^{\circledR}$ AIRC): An overview,
J. Geophys. Res., 116, D00K34, doi:10.1029/2010JD015257, 2011.

Li, Z. Q., Xia, X. G., Cribb, M., Mi, W., Holben, B., Wang, P., Chen, H. B., Tsay, S. C., Eck, T. F., Zhao, F. S., Dutton, E. G., and Dickerson, R. E.: Aerosol optical properties and their radiative effects in northern China, J. Geophys. Res., 112, D22S01, doi:10.1029/2006JD007382, 2007a.

Li, Z. Q., Chen, H., Cribb, M., Dickerson, R. E., Holben, B., Li, C., Lu, D., Luo, Y., Maring, H., Shi, G., Tsay, S.-C., Wang, P., Wang, Y., Xia, X., Zheng, Y., Yuan, T., and Zhao, F.: Preface to special section on East Asian Studies of Tropospheric Aerosols: An International Regional Experiment (EAST-AIRE), J. Geophys. Res., 112, D22S00, doi:10.1029/2007JD008853, 2007b.

Li, Z., Gu, X., Wang, L., Li, D., Xie, Y., Li, K., Dubovik, O., Schuster, G., Goloub, P., Zhang, Y., Li, L., Ma, Y., and Xu, H.: Aerosol physical and chemical properties retrieved from ground-based remote sensing measurements during heavy haze days in Beijing winter, Atmos. Chem. Phys., 13, 10171-10183, doi:10.5194/acp13-10171-2013, 2013.

Liang, F. and Xia, X. A.: Long-term trends in solar radiation and the associated climatic factors over China for 1961-2000, Ann. Geophys., 23, 2425-2432, doi:10.5194/angeo-23-2425-2005, 2005.

Luo, Y., Lu, D., Zhou, X., Li, W., and He, Q.: Characteristics of the spatial distribution and yearly variation of aerosol optical depth over China in last 30 years, J. Geophys. Res., 106, 14501-14513, 2001.

Qiu, J. and Yang L.: Variation characteristics of atmospheric aerosol optical depths and visibility in North China during 1980-1994, Atmos. Environ., 34, 603-609, 2000.

Nakajima, T. and Tanaka, M.: Algorithms for radiative intensity calculations in moderately thick atmospheres using a truncation approximation, J. Quant. Spectrosc. Ra., 40, 51-69, 1988.

Ramanathan, V., Crutzen, P. J., Lelieveld, J., Mitra, A. P., Althausen, D., Anderson, J., Andreae, M. O., Cantrell, W., Cass, G. R., Chung, C. E., Clarke, A. D., Coakley, J. A., Collins, W. D., Conant, W. C., Dulac, F., Heintzenberg, J., Heymsfield, A. J., Holben, B., Howell, S., Hudson, J., Jayaraman, A., Kiehl, J. T., Krishnamurti, T. N., Lubin, D., McFarquhar, G., Novakov, T., Ogren, J. A., Podgorny, I. A., Prather, K., Priestley, K., Prospero, J. M., Quinn, P. K., Rajeev, K., Rasch, P., Rupert, S., Sadourny, R., Satheesh, S. K., Shaw, G. E., Sheridan, P., and Valero, F. P. J.: Indian Ocean Experiment: an integrated analysis of the climate forcing and effects of the great Indo-Asian haze, J. Geophys. Res., 106, 28371-28398, 2001.

Smirnov, A., Holben, B. N., Eck, T. F., Dubovik, O., and Slutsker, I.: Cloud screening and quality control algorithms for the AERONET database, Remote Sens. Environ., 73, 337-349, 2000.

Stamnes, K., Tsay, S. C., Wiscombe, W., and Jayaweera, K.: Numerically stable algorithm for discrete-ordinate-method radiative transfer in multiple scattering and emitting layered media, Appl. Opt., 27, 2502-2509, 1988.

Takamura, T. and Nakajima, T.: Overview of SKYNET and its activities, Optica Pura y Aplicada, 37, 3303-3308, 2004.

Tang, J., Wang, M., and Cheng, H.: Variation Characteristics of Ambient NMHCs at Shangdianzi and Lin'an Regional GAW Sites, Acta Meteorol. Sin., 21, 334-341, 2007.

Tao, R., Che, H. Z., Chen, Q. L., Wang, Y. Q., Sun, J. Y., Zhang, X. C., Lu, S., Guo, J. P., Wang, H., and Zhang, X. Y.: Development 
of an integrating sphere calibration method for Cimel sunphotometers in China aerosol remote sensing network, Particuology, doi:10.1016/j.partic.2013.04.009, in press, 2014.

Wang, H., Zhao, T. L., Zhang, X. Y., and Gong, S. L.: Dust direct radiative effects on the earth-atmosphere system over east Asia: Early spring cooling and late spring warming, Chinese Sci. Bull, 56, 1020-1030, doi:10.1007/s11434-011-4405-3, 2011.

Wang, J. and Christopher, S. A.: Intercomparison between satellitederived aerosol optical thickness and $\mathrm{PM}_{2.5}$ mass: implications for air quality studies, Geophys. Res. Lett., 30, 2095, doi:10.1029/2003GL018174, 2003.

Wang, Q., Shao, M., Zhang, Y., Wei, Y., Hu, M., and Guo, S.: Source apportionment of fine organic aerosols in Beijing, Atmos. Chem. Phys., 9, 8573-8585, doi:10.5194/acp-9-8573-2009, 2009.

Watson, J. G.: Visibility: Science and Regulation. J. Air Waste Manage. Assoc., 52, 628-713, 2002.

Xia, X. A., Chen, H. B., Wang, P. C., Zong, X. M., and Gouloub, P.: Aerosol Properties and Their Spatial and Temporal Variations over north China in Spring 2001, Tellus B, 57, 28-39, 2005.

Xia, X., Chen, H., and Zhang, W.: Analysis of the dependence of column-integrated aerosol properties on long-range transport of air masses in Beijing, Atmos. Environ., 41, 7739-7750, 2007a.

Xia, X., Chen, H., Goloug, P., Zhang, W., Chatenet, B., and Wang, P.: A compilation of aerosol optical properties and calculation of direct radiative forcing over an urban region in northern China, J. Geophys. Res., 112, D12203, doi:10.1029/2006JD008119, $2007 b$.

Xia, X.: A closer looking at dimming and brightening in China during 1961-2005, Ann. Geophys., 28, 1121-1132, doi:10.5194/angeo-28-1121-2010, 2010.

Xia, X., Chen, H., Goloub, P., Zong, X., Zhang, W., and Wang, P.: Climatological aspects of aerosol optical properties in North China Plain based on ground and satellite remote-sensing data, J. Quan. Spec. Rad. Trans., 127, 12-23, 2013.
Xu, J., Bergin, M. H., Yu, X., Liu, G., Zhao, J., Carrico, C. M., and Baumann, K.: Measurement of aerosol chemical, physical and radiative properties in the Yangtze delta region of China, Atmos. Environ., 36, 161-173, 2002.

Xu, X., Xie, L., Ding, G., and Bian, L.: Beijing air pollution project to benefit 2008 Olympic Games, Bull. Amer. Meteor. Soc. , 86, 1543-1544, 2005.

Yang, M., Howell, S. G., Zhuang, J., and Huebert, B. J.: Attribution of aerosol light absorption to black carbon, brown carbon, and dust in China - interpretations of atmospheric measurements during EAST-AIRE, Atmos. Chem. Phys., 9, 2035-2050, doi:10.5194/acp-9-2035-2009, 2009.

Zhang, J. K., Sun, Y., Liu, Z. R., Ji, D. S., Hu, B., Liu, Q., and Wang, Y. S.: Characterization of submicron aerosols during a serious pollution month in Beijing (2013) using an aerodyne high-resolution aerosol mass spectrometer, Atmos. Chem. Phys. Discuss., 13, 19009-19049, doi:10.5194/acpd-13-19009-2013, 2013a.

Zhang, R., Jing, J., Tao, J., Hsu, S.-C., Wang, G., Cao, J., Lee, C. S. L., Zhu, L., Chen, Z., Zhao, Y., and Shen, Z.: Chemical characterization and source apportionment of $\mathrm{PM}_{2.5}$ in Beijing: seasonal perspective, Atmos. Chem. Phys., 13, 7053-7074, doi:10.5194/acp-13-7053-2013, 2013 b.

Zhang, X. Y., Wang, Y. Q., Niu, T., Zhang, X. C., Gong, S. L., Zhang, Y. M., and Sun, J. Y.: Atmospheric aerosol compositions in China: spatial/temporal variability, chemical signature, regional haze distribution and comparisons with global aerosols, Atmos. Chem. Phys., 12, 779-799, doi:10.5194/acp12-779-2012, 2012. 